\title{
Giving Unwanted Gifts: Political Economy of YouTube Apology
}

\author{
Eka Sri Dana Afriza ${ }^{1 *}$, Udi Rusadi ${ }^{2}$ \\ ${ }^{12}$ Universitas Sahid, Sahid Sudirman Residence, Jakarta 10220, indonesia
}

\begin{abstract}
A B S T R A C T
A public apology is fairly common content found on the YouTube platform to restore the reputation and regain people's trust. At the same time, YouTube can also be used as a commodity-based economic platform that allows organizations, individuals, and Google (the owner of YouTube) to earn revenue either through advertising or direct promotion. These two things reflect the dual benefits of two opposites: genuine demand in the public interest and economic exploitation for the benefit of certain parties. This is well explored by the political economy theory of media which sees the digital platform as a convergence between the moral economy of commodities, the moral economy of gifts, and the moral economy of public goods. This article aims to further explore the three elements of the political economy of the media in the context of apologies on YouTube in five cases that occurred in Indonesia. The five apology cases were analyzed using parameters reflecting the moral economy of commodities, gifts, and public goods. The results of the analysis provide a typology of apology.
\end{abstract}

ART ICLE INFO

\author{
Article History: \\ Received : 30-05-2021 \\ Revised : 03-10-2021 \\ Accepted : 23-10-2021 \\ Published : 31-10-2020
}

\section{Keywords:}

YouTube Apology

Media Political Economy

Moral Economy

Commodity

Gift Economy

JEL: M10, M20, M30

*Corresponding Author E-mail:

dana.afriza@gmail.com

Copyright (C) 2021 Authors. This is an open access article distributed under the Creative Commons Attribution License (CC-BY-SA 4.0) which permits use, distribution and reproduction in any medium, provided the original work is properly cited \& ShareAlike terms followed.

\section{INTRODUCTION}

Post Eid Al-Fitr 2021, the Indonesian public is confronted by several viral videos on social media that show apologies, ranging from apologies for people who scolded the courier for goods not being ordered (Tribun Jatim Official, 2021; Tribunnews.com, 2021) to apologies of students who insulting Palestine (Kompas, 2021a). These videos remind the public of the ability of the public to pressure the perpetrator via YouTube so that the perpetrator is forced to give an apology to the public.

YouTube Apology literature is generally viewed 
from a business perspective as a form of reputation restoration (Sandlin \& Gracyalny, 2018), a linguistic perspective as a form of pragmatism (Abudin \& Sundari, 2021), or from a management perspective as a form of crisis communication (Sandlin \& Gracyalny, 2020). The weakness of these three approaches is to view YouTube Apology from a limited perspective, especially from the perspective of the wrongdoer. Meanwhile, YouTube Apology is very diverse. The source of information and the perpetrator apologizing may differ. The parties to the apologies also vary. As a result, a more comprehensive framework is needed in understanding YouTube Apology.

The political economy of the media (Murdock, 2011) can examine this issue by looking at its relation to three moral economies: a commodity economy, a gift economy, and a public goods economy. Even so, until now the issue of apology via YouTube has hardly been touched from the political economy perspective of the media.

The political economy framework of the media sees cyberspace as a system in which the commodity economy, gift economy, and public goods economy are intertwined in a complex and mutually influencing manner (Murdock, 2011). What is seen solely as the domain of a public goods economy can have a commodity dimension and a gift dimension. When we look at the apology video at a glance, the dimension that stands out is the economy of the public goods. Although YouTube is a private good because it was created with private funding, the Internet is a public good. The government allocates a tax budget to manage and regulate the distribution of its infrastructure in a country (Canazza, 2018). It is also a commodity because it can generate money and is a gift item because the public can share with anyone at any time without expecting financial incentives from the public. YouTube itself clearly states this trait. YouTube's mission is to give everyone the freedom to express, get information, use opportunities, and have a place to work (YouTube, 2021).
This study's main research question asked: how YouTube apology related to the commodity economy, gift economy, and public goods economy of the media? The outcome of this process is a typology that describes how three types of moral economy, according to Murdock's (2011) political economy theory of media, play a role in YouTube apology. The method used in this study is a secondary data review method in the form of YouTube apology videos made in Indonesia.

\section{LITERATURE REVIEW}

The political economy of media described by Murdock was indeed developed from a critical perspective. Murdock describes three moral economic systems, namely the capitalist economic system, the public economic system, and the civil society economic system (sharing economy)(Murdock, 2011).

The capitalist economic system that relies on commodities and commodification is an easy target for a critical perspective. A capital economic system is a place where the disposition (seizure) of public property becomes one's property. Murdock gave an example of how in the Tudor era (England 1400-1600 AD), land that was initially free for everyone to collect firewood and raise livestock, was then taken and fenced off by 'agricultural entrepreneurs' who made it private property. Since then, residents have had to work and earn money to graze and collect firewood. This is what Harvey later called the new style of imperialism (Harvey, 2003).

There is no need to be far away, in Kalimantan and perhaps in other areas, this phenomenon is very pronounced, especially in rural communities whose land has turned into oil palm plantations or turned into industrial estates. The people, who initially made enough food by fishing and collecting wild plants in the forest for vegetables, have now lost it all. The water has become polluted and the fish have disappeared, while the land has become mills and oil palm plantations. Like it or not, to find food, people have to work and the closest job with minimal transportation costs is to work in the mill or the oil palm plantation. 
People who can only fish and hunt but cannot or are willing to work as laborers end up becoming thugs and unemployed who are stalked and arrested by company security. With this, the company claims to have utilized local labor and created peace in the community, even though it could be that this peace is an illusion created by first taking people's rights to their land. This could be positive for a fortunate citizen because he or she also gets a salary that can buy necessities beyond fishing and collecting fruit and vegetables (which now also have to be bought for consumption). But the worrying impact is of course on the community, the elderly for example, who can only fish and collect fruit and vegetables to live. Their fate ultimately depends on a living, albeit dim, sharing economy in an increasingly capitalistic society.

Murdock (2011, p.20) himself states that cultural goods and communication have three relationships with commodity culture. The first link is that there are many media products and cultural services which are commodities in themselves. This relationship is an area of intense critical theory investigation. The critical study examines this relationship by highlighting the potential control over public culture and debates about private ownership and the dynamics of profit maximization; and creating substantial inequalities in participating capacities by tying access to communications with the ability to pay. Another link is that the media provide the primary platform for advertising and promoting common commodities, and the dominant genre of popular media extends the naturalization of commodity culture by filling expressive spaces with images of locations and people who present them as definite social acts (capitalist realism). Murdock (2011, p. 20) refers to Horkheimer's critique of capitalist realism by providing examples of how bright blue skies are part of both Disney's landscape and its commercials. This is the reality of the formation of capitalism and critical perspectives are very suspicious of these conditions.

The second moral economic system, namely the public economic system, is also subject to a critical perspective. The essence of the public economic system is the existence of public goods both in the form of public spaces and in the form of public cultural services (eg libraries). Murdock tells how it happened in 1856 when the central area of London, which was originally a public space, then turned into a commercial area with so many fenced spaces complete with guards due to intense competition from landlords in the area. After intense public protests, to demonstrations that dismantled the fence of private areas, the government finally gave access to citizens by making the central area of London a public area (Minton, 2013).

In this system, there is a tendency for the government to get rid of class solidarity by encouraging users of public goods to become members of the national or local community. Governments and experts determine what art to show, what books to keep in the library, and what ideas to teach in school. While this prevents political power from entering, it also removes the perspectives of the vernacular and the general public. Murdock (2011, p.22) explains how this hegemony was undermined by audiences themselves in the late 19th and early 20th centuries through the spirit of shared knowledge and made books accessible to all, even those who could not read, through reading. loud by 'readers' at work, pubs, and street corners.

The third moral economic system, the system of giving (sharing), is exemplified by Franz Boas' observations on the Kwakiutl people in Canada before the period of British colonialism and the modernity of capitalism. In this society, there is a potlach ritual, which is a ritual of distributing property to the community. Chieftains and prominent people did this to legitimize their status in society. In 1849, the British came and tried to incorporate the Kwakiutl tribe into the economic system of capitalism. Now, ordinary people can organize potlach, no longer the chiefs of tribes. This resulted in competition within Kwakiutl society where there were more and more potlach ceremonies with more and more 
gifts from tribal chiefs and people who became wealthy because of capitalism. In 1862, there was a smallpox epidemic that was brought by the British colony into the Kwakiutl society. Twothirds of the indigenous Kwakiutl people died. This time, there is another potlach spike organized by the family members of the deceased as part of the deceased's attempt to reclaim his life. In the end, in 1884, colonial Britain banned and convicted anyone who organized potlach. With the potlach gone, so too was the sharing economy. All goods had to be bought and the Kwakiutl people entered the world of pure capitalism.

Murdock also recounts how Marcel Mauss's observations of Paris in the 1920s became a world of pure capitalism, as did Richard Titmuss' observations of England in the 1960s. Everything continues today. The only difference is that in these European countries, the public interest is replaced by the interests of capitalism, while in Kwakiutl, the interests of civil society are changed to the interests of capitalism. The point is that in the current world political-economic system, there is an imbalance where the commodity-based capitalist economic system devours a public economic system based on democracy and a civil society economic system based on the norms of reciprocity between members of society.

The sharing economy, as the name implies, is not purely free. Giving must be reciprocated, it's just with other gifts that do not need to be the same, the important thing is that the party who previously gave is considered equal. Even giving money to beggars is a reciprocal process. At least the person giving the money expects a thank you or a smile from the beggar who is given it.

Departing from the above typology, Murdock (2011) entered the modern world and information technology. The internet world is a new ground to open up space for the three types of moral economy. Digital capitalism leads to the consequence of the duality of knowledge under information and experience. In this sense, the internet creates "noble amateurs" whose strength is determined by popularity (Murdock,
2011, p. 36). This seems to be similar to the traditional Kwakiutl elders whose power is determined by contributions to society. But popularity is not a gift, it is just a forum for the spontaneity and authenticity of the audience. What this means is that the characters who appear on the internet do not appear because of their real contribution to society but on how they are liked based on the similarity or identity of their audiences. Whether it's celebrities who commodify their personal lives or 'ulama' making up extreme and shocking opinions based on conspiracy theories and common sense. As a result, the audience does not get anything new that can increase their knowledge, but just admiration and narcissism for themselves and retain their old knowledge that could be, without scientific basis. Capitalism then takes advantage of this audience tendency as a source of income and continues to support this trend to become increasingly extreme through, for example, the user-targeted ad, which provides advertisements according to the hobbies and preferences of the audience.

Murdock does not provide a visual representation of his model of the political economy theory of media. Based on the reading of what Murdock has described, the authors construct a political economy model of Murdock's media as shown in Figure 1.

The author sees that the root of the initial problem of political economy issues is the existence of goods in human life. The exchange of goods between people then leads to three conceptions of a moral economy based on the nature of goods: a commodity-based moral economy, a gift-based moral economy, and a moral economy based on public goods. If goods are considered as commodities, then the issue that arises is ownership (possession) which will have implications for disposition. If goods are considered gifts, then the issue that arises is goodness, which naturally implies reciprocity. If the goods are considered a public good, then the issue that arises is reclaiming. It is said to reclaim it because it tries to take back goods 
that are privately owned as if these goods were commodities.

The competition between these three moral economies gives rise to a political character that brings tug-of-war in the ownership of goods (private, shared, or public property). In the context of the digital economy, this competition is manifested in a tug of war or convergence swings, namely the direction in which the digital medium is being taken: whether towards information and experience as pursued by a commodity-based moral economy, or towards knowledge as pursued by a public goods-based moral economy.

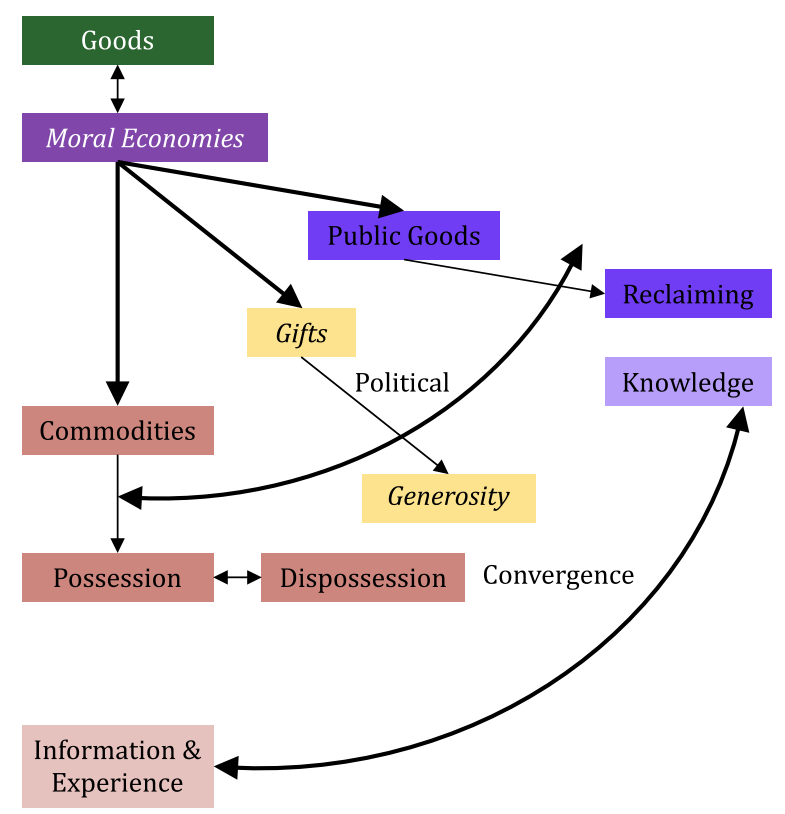

Figure 1. Murdock's Political Economy Model (self-developed)

\section{RESEARCH METHOD}

The purpose of this research is to analyze YouTube apology as a political economy phenomenon in Indonesian media. This research uses Murdock's (2011) political economy theory of media which distinguishes three types of moral economy: a moral economy, a moral economy of gifts, and a moral economy of public goods. The question then is how these three types of moral economy are examined using YouTube videos.

This research uses a multiple case studies approach. Multiple case studies allow general trends between cases to emerge from unique patterns in individual cases (Eisenhardt, 1989). In addition, the use of multiple case studies allows the disclosure of complex relationships taking into account the context (Yin, 2018). This in turn allows the researcher to draw a theoretical picture based on the general trend that exists in all cases.

We choose five cases from the list of apologizing YouTubers created by Diananto (2020). The five cases used for analysis in this study include the cases of Indira Khalista, Gritte Agatha, Hassanjr11, AlehAleh Khas Medan, and FerdianPaleka. The five cases occurred in April - May 2020.

We studied the similarities and differences in the apology patterns that YouTubers made based on the data available in the list of videos that were on their accounts, before, during, and after the event occurred. In cases where the video upload stops when the event occurs, and therefore no after events can be detected in the video list, we are looking for a replacement YouTuber account with the keyword name YouTuber on the YouTube site. In addition to looking at the title and content of the video, we also look at the statistics of the video such as views, likes, dislikes, comments, and subscribers, as well as the statistics of the channel, namely the frequency of YouTuber uploads. We also investigate the timeline of the case and relevant events until no more patterns can be observed.

By the theory that forms the basis of this research, we use three categories, namely the moral economy of commodities, the moral economy of gifts, and the moral economy of public goods. The criteria for each category are as follows:

1. The moral economy of commodities (MEC) deals with commodity goods that are traded, including advertisements and content. YouTubers can monetize their videos and the amount of money earned depends on the number of ads and the number of views, subscribers, likes, and comments he gets. But what is more important from a commodities perspective is the account itself. As a result, the moral economic parameter of the 
commodity, related to the YouTube apology lies in what channel the apology is given and whether there is an explicit request for feedback to those watching in the standard form, namely like, comment, and subscribe, because this indicates that the audience is asked to donate a small amount of money to the apology video giver.

2. The moral economy of gifts (MEG) relates to how much likes, relative to dislike, of apology videos. This parameter is taken as an economic indicator of moral gifts because it reflects how consumers give positive or negative returns on gift transactions that occur.

3. The moral economy of public goods (MEPG) is related to how many views a video gets relative to other videos uploaded by the same account. We use views as the indicator since this relates to the public as a whole, not just subscribers or haters of the account. This indicates the great public interest in the apology. Because one account will be able to upload a large number of videos throughout its history and there is no direct statistical parameter that gives the average view value for each video, the researchers used the video that was uploaded most recently after an apology and most recently after an apology from that account.

\section{RESULT AND DISCUSSION}

The data used for the analysis is presented in Table 1 below. The description of the data and the general pattern of each apology case are described after the table.

Notes: $\mathrm{MEC}=$ moral economy of commodity parameter (the availability of likes, comments, and subscribe in the apology content), MEG = moral economy of gift parameters, $\mathrm{MEPG}=$ moral economy of public goods, NA = not available, $\mathrm{VAV}=$ views of the apology video, VPre = views of the pre-apology event, VPost = views of the postapology event.

The Indira Khalista's and Gritte Agatha's cases are related because the two YouTubers made a mistake together. Indira Khalista and Gritte Agatha are considered to have underestimated Covid-19 by telling and revealing that Indira Khalista only wears a mask if warned. Gritte Agatha in this case as an interviewer failed to remind and remove this statement so that it became viral. The video entitled "Indira Kalistha Was Interviewed Seriously for the First Time" was later deleted. The video channel is Gritte Agatha with a subscriber of 4.39 million and focuses on talk shows with artists and ordinary people who experience extraordinary problems, for example in debt due to online loans. Three days after the video went viral, Indira and Gritte apologized in their ways. Indira apologized in an interview with DeddyCorbuzier on the channel with the same name, which has a subscriber of 14.4 million people. This video has 9.5 million views, with 375 thousand likes and 72 thousand dislikes, and 163 thousand comments. Indira has its channel but chooses to use DeddyCorbuzier as an apology channel (Corbuzier, 2020). This is probably because Deddy has far more subscribers than Indira or Gritte.

Meanwhile, Gritte made an apology on a private channel, the same channel where the video of the error was made (Agatha, 2020). This video is only 2 minutes long, in contrast to Gritte's videos, which are generally 20 minutes long. This makes

Table 1. Data used in the analysis

\begin{tabular}{|c|c|c|c|c|c|c|c|c|}
\hline & \multirow[t]{2}{*}{ YouTuber } & \multirow[t]{2}{*}{ MEC } & \multicolumn{3}{|c|}{ MEG } & \multicolumn{3}{|c|}{ MEPG } \\
\hline & & & Likes & Dislikes & Ratio & VAV & Vpre & Vpost \\
\hline 1 & Indira Khalista & NA & 375,000 & 72,000 & 5.21 & NA & NA & NA \\
\hline 2 & Gritte Agatha & None & 173,000 & 13,000 & 13.31 & $2,344,929$ & 793,744 & 366,143 \\
\hline 3 & Hasan JR 11 & NA & NA & NA & NA & NA & 453,073 & $1,567,814$ \\
\hline 4 & Aleh Aleh Khas Medan & None & $4,700.00$ & 142 & 33.10 & 76,286 & NA & 140,296 \\
\hline 5 & Ferdian Paleka & NA & NA & NA & NA & NA & NA & NA \\
\hline
\end{tabular}


the video straight to the point. Also, the short duration of videos prevents videos from being commercialized because short videos cannot be monetized. The Gritte Channel is a very productive channel with 1-2 videos uploaded daily. But after the apology video, a new video was uploaded on May 27, 11 days later. YouTube rules themselves will provide a strike or punishment for videos that violate the policy by blocking uploads for 7 days. This represents a more than four-day extension of Gritte's self-made. The video of Gritte's apology was watched 2.3 million times with 173 thousand likes and 13 thousand dislikes and 16 thousand comments.

The third case is the Hassanjr11 case, which was protested for making a video challenging people to break their fast with the lure of 10 million in cash. This video has been removed by HassanJr11. Hassan himself has 6 million subscribers with an average upload frequency of one video per week. Hassan channel focuses on social experimentation such as pretending to be a ruffian, and also pranks such as pranking mature girls. Because of this incident, Hassanjr apologized via Instagram, not via YouTube. Likes, dislikes, and comments for videos before uploading is disabled. The incident is expected to occur on April 27, 2020, but uploading the next video will only start on June 6 , 2020. This means that there is a month after the incident where HassanJr11 no longer makes videos.

The fourth and fifth videos culminate in imprisonment for the two YouTubers. The fourth video was made by Aleh-Aleh Khas Medan who is considered to be insulting Islam because he made a parody of the song "Aisyah Istri Nabi" (Aisha, the Wife of the Prophet). The YouTuber who owns this account was arrested by the police and jailed (Tribunnews.com, 2020). The apology was conveyed through the media witnessed by the police. After leaving prison a few months later, this YouTuber created a new account that still focuses on prank content. Even so, the first video on the new account is a heartwarming official apology to viewers. The video entitled "Aleh-Aleh returns" was watched 76 thousand times with five thousand likes and 142 dislikes (Aleh Aleh Khas Medan, 2020). The 7-minute video contains YouTuber's regret and the compassion of YouTuber's apology to his mother.

The fifth video is considered to be harassing the transgender community, uploaded by YouTuber FerdianPaleka. This YouTube channel has been deleted. The title of the video in question is "Food Delivery Prank to CBL transgenders". Previous channel content did focus on prank activity. Ferdian was arrested by the police and made an apology escorted by the police in front of the media. After his release from prison, Ferdian made a now-deleted video, entitled "I'm sorry"(Bebey, 2020). After that, Ferdian created a new channel, Paleka TV, starting from scratch.

From the five cases above, we can see some strategies that allow an apology to be conveyed sincerely, and the YouTuber's reputation is regained. But if we look at it from the perspective of the political economy of the media, things are even more complex. The commodity economy emerged when these videos became popular, and because of this, earned money that became income for the YouTubers. When YouTube realizes that the content contains policy violations, this flow of funds can be stopped and the YouTuber is penalized for not being able to upload videos for one week. But at the same time, other the YouTubers and the media, get income for reporting and criticizing these videos. Until now, videos that are reposts of original videos that violate this policy are still on various other channels. That is, there is still a commodity economy flowing because of a violation.

After the apology, the YouTubers understand that they must prevent monetization of their apology video. Hence we see that MEC is none for the apology posted on YouTube. None of the apology videos uploaded by the perpetrators themselves asked for likes, comments, shares, and subscriptions to viewers. MEC with NA sign indicated another strategy to evade monetization since there is no video at all. In the first case, the YouTuber uses another channel to apologize. 
But it does drain income to the channel owner because of the large views of the interview video. In the second case, the YouTuber apologized to her channel but prevented monetization by making a short video. In the third case, The YouTuber apologized through other social media, not via YouTube, so that he also avoided monetization. In the fourth and fifth cases, the first apologies were delivered indirectly, mediated by the police. The profits arising from this apology video flow to the mass media who report the apology on their television and YouTube channel.

Turning to the moral economy of gifts, the like and dislike comparison can only be done for three videos: the first, second, and fourth cases. In the first video, the ratio of likes (375 thousand) to dislike (72 thousand) was 5.2. The second video has a ratio of 13.3 and the fourth video has a ratio of 33.1. This suggests that emotionally self-made videos (fourth video) have a higher public impact than rationally self-made videos (second video), let alone videos made by other channels (first video). Further, all the ratios are larger than one. This reaffirms the positive nature of the apology since a ratio lesser than one could indicate more dislikes than likes, which is not the case in these videos. The prize economy stands out in the fourth case where the troubled YouTuber started a new channel by apologizing and gain a ratio of 33.10 . This implies that he asked the audience back the confidence in himself that had lost, and the audience began to like him again. The prizes were given by the second, fourth, and fifth YouTubers are content that promises to be better, more moral, and more educational.

The moral economy of public goods can be seen from the public response to the apology videos. For the second case, the apology video gains the largest attention, while for the fifth case, the apology video has the least attention. Further conclusion, such as whether the apology increased or decreased future videos views cannot be determined since many external factors, such as internet penetration or competition between YouTubers, could be accountable for the increased or decreased videos views after the apology. Comparison with apology video views of other cases also cannot be determined since the apology is posted on the other's account (first case), not in YouTube (third case), and the video erased (fifth account). Despite this, the public responses are high for the accounts if the account continued (second case) and have no criminal consequences.

Interestingly, the pattern found in these five cases is very diverse. Each YouTuber follows different routes after the events. However, from these five cases, we can make a YouTube apology video typology as in the following table. This typology is built on the channel where the apology is issued. There are five types of channels, namely author own channel, other channel, news media, author new channel, and other social media. In the author's channel, the owner has the potential to monetize videos but chooses not to. Even so, YouTube can still benefit, and so can news media and other channels. YouTube's new policy as of 25 May 2021 is that YouTube can advertise on all its videos without exception (Kompas, 2021b). This means that the only way for YouTube not to earn income from apology is to make statements in other media such as Instagram or Twitter. Even this is only indirect. The media or other users can use their YouTube channel to report the apology and because of this, YouTube also gets revenue from this news. Videos that violate the provisions need to be removed and there will be a period of 'grieving' for the YouTubers for some time before uploading new content. But this approach can be very effective because it allows the YouTuber involved to make an emotional apology.

In cases where an apology is created on another channel, the channel owner is freed from the burden of guilt and can therefore monetize and request rewards (likes, comments, subscribe, share) from the apology video. Likewise in the case when the apology is carried out through news media, where the news media can monetize the video. 
Table 2. Political Economy Typology of YouTube Apology

\begin{tabular}{llll}
\hline Channel & \multicolumn{1}{c}{ Commodities } & \multicolumn{1}{c}{ Gifts } & \multicolumn{1}{c}{ Public Goods } \\
\hline $\begin{array}{l}\text { Author } \\
\text { Own }\end{array}$ & $\begin{array}{l}\text { Potential only for the owner, the owner } \\
\text { could shorten the video to reject monetization. } \\
\text { However, YouTube still profited from the new } \\
\text { policy, as 25 May 2021 where YouTube could } \\
\text { put an advertisement in all videos without } \\
\text { exception (Kompas, 2021); news media and } \\
\text { another channel could monetize the apology }\end{array}$ & $\begin{array}{l}\text { The author could stop } \\
\text { upload the new video until } \\
\text { several weeks or months } \\
\text { later }\end{array}$ & $\begin{array}{l}\text { Could be highly emotional } \\
\text { and gain forgiveness }\end{array}$ \\
& $\begin{array}{l}\text { The owner of the channel gets profit. YouTube, } \\
\text { news media, and other channels could monetize } \\
\text { the apology }\end{array}$ & $\begin{array}{l}\text { The owner of the channel } \\
\text { could ask more subscribers, } \\
\text { likes, shares, and comments }\end{array}$ & $\begin{array}{l}\text { Little effect compared to } \\
\text { author own channel }\end{array}$ \\
$\begin{array}{l}\text { Channel } \\
\text { Mews }\end{array}$ & $\begin{array}{l}\text { News media and other channels in Television } \\
\text { and YouTube get the profit, as well with }\end{array}$ & $\begin{array}{l}\text { The owner of the channel } \\
\text { could ask more subscribers, } \\
\text { likes, shares, and comments }\end{array}$ & $\begin{array}{l}\text { Gain wider attention from the } \\
\text { public since shared to many } \\
\text { news media in many forms }\end{array}$ \\
\hline $\begin{array}{l}\text { Yuthor } \\
\text { New } \\
\text { Channel }\end{array}$ & $\begin{array}{l}\text { Could be a form of social capital to build new } \\
\text { contents to gain money }\end{array}$ & $\begin{array}{l}\text { The owner of the channel } \\
\text { promised better contents }\end{array}$ & $\begin{array}{l}\text { The new beginning. Small } \\
\text { attention since very few people } \\
\text { know the existence of the } \\
\text { channel at first }\end{array}$ \\
\hline $\begin{array}{l}\text { Other } \\
\text { Social } \\
\text { Media }\end{array}$ & $\begin{array}{l}\text { The new social media, like Instagram or } \\
\text { Twitter, that gain profit }\end{array}$ & $\begin{array}{l}\text { The old video could be } \\
\text { erased and because no } \\
\text { apology video on the } \\
\text { channel, the channel on } \\
\text { YouTube looks like having } \\
\text { no problem }\end{array}$ & $\begin{array}{l}\text { People on YouTube could still } \\
\text { wonder why there are no } \\
\text { uploads for some time. } \\
\text { The quality change could } \\
\text { imperceptible since the theme } \\
\text { of the channel is not changed }\end{array}$ \\
\hline
\end{tabular}

Source: own analysis

The owner can create a new YouTube channel as a fresh start and open with a sincere apology. But it starts from scratch and takes a long time to get back subscribers. Very few people will be aware of this new channel the first time it is uploaded. However, a live apology video as the start of a new channel is a morally acceptable step.

The strategy of using other social media such as Twitter and Instagram will not change the remaining positive image of the YouTube channel. You just need to delete the negative content on the channel. Since there are no apology videos, less informative visitors will not think the channel has had issues in the past. It will be even more obscure if the upload frequency has barely changed and the video theme hasn't changed much either.

Overall, the above findings reaffirm that the internet is becoming an intertwining of the three moral economies (Murdock, 2011). It is quite impressive that the commodity and gift-based YouTube system has an impact on the public goods economy and the public goods economy provides corrections that return to benefit the commodity economy and gift economy, even if the YouTuber who creates negative content does not want it and is not aware of it.

YouTube Apology is a research theme that is still very new and has not been touched upon except from a reputation perspective (Sandlin and Gracylany, 2018). Research in the context of political apology has emerged but more on television media (Ahn \& Lin, 2019). Kadar et al (2018) analyzed the broader context, namely the apology of public rituals by highlighting the strategies of an apology being undertaken, one of which was using video. This research, therefore, contributes to the literature on YouTube Apology by contributing to a more general concept of public ritual apology(Kadar et al., 2018) and a broader theoretical basis.

Previous research also touched on the emergence of the phenomenon of negative affection vlogs on YouTube where the audience consumed tears to exchange authenticity and self-therapy (Berryman \& Kavka, 2018). This phenomenon is in contact with an apology video on YouTube which also reflects the productivity of negative affections, 
where apologies are accepted gracefully by the community and YouTubers can restart their programs according to their respective missions.

\section{CONCLUSION AND RECOMMENDATION}

An important finding from this research is that apology via YouTube from the perspective of the political economy of the media has the dimensions of commodities, gifts, and public goods. The shape of the dimension of each of these moral economies depends on what channel the apology is based on. If an apology is made in the news media, then the moral economy of commodities will fall into the hands of the mass media, and gifts are spread to many recipients. If mistakes or apologies are deliberately recorded by the perpetrator, the moral economy of the commodity falls into the hands of the perpetrator and the reward is also focused on the perpetrator. The moral economy of public goods is the determinant of value for content, whether negative or positive, which in the case of this study covers the themes of religion, health, and human rights.

This research is still very limited because it uses a small sample size and also uses debatable measurement parameters. Future research needs to use a larger sample and use more precise and precise measurement parameters to identify the features of the video that characterize each moral economy.

However, this research has theoretical and practical implications. The theoretical implication of this research reaffirms the political economy theory of media as an approach that can comprehensively parse various phenomena in utilizing social media, especially visual social media such as YouTube. In particular, the political economy theory of media can be used to analyze phenomena from outside a particular moral economic system that seems unrelated to a political issue. Videos about the public interest can be about the commodity economy and the gift economy, and vice versa. In the end, this also confirms the thesis of the political economy theory of media that the internet is a convergence tool that allows all moral economic systems to mix to form one complex system of knowledge, information, and experience.

The most practical implication is how social media, especially YouTube, as well as users, both viewers and uploaders, must pay attention to the publicity in this media. The economic boundaries of public morals must be carefully considered so that YouTube consumption is always healthy and benefits all parties. Indeed, this research has shown that there are still many parties who will benefit when negative content and apologies are created, but the perpetrators can have a severe impact. A YouTuber can be jailed for the negative content he creates and this is certainly a sadness that should not be used except as a lesson so that the same thing does not happen again. Human tend to give surprising goods, rather than something useful goods for the something in need (Yang \& Urminsky, 2018). A YouTuber needs to give both, for the sake of the contents and the sake of the receiver.

\section{REFEREN CES}

Abudin, B., \& Sundari, H. (2021). Exploring Apology Strategy by Indonesian Public Figures: A Pragmatic Study in Social Media. Deiksis, 13(2), 122-133.

Agatha, G. (2020). Apology... (In Indonesian). YouTube. https://www.YouTube.com/watch?v=VxYuIu540TA Ahn, J.-H., \& Lin, T. (2019). The politics of apology: The 'Tzuyu Scandal' and transnational dynamics of K-pop. International Communication Gazette, 81(2), 158-175. https://doi.org/ $10.1177 / 1748048518802947$

Aleh Aleh Khas Medan. (2020). Aleh Aleh Returns (In Indonesian). https://www.YouTube.com/watch?v=eClMTAaoiJE 
Bebey, A. (2020). YouTuber Ferdian Paleka Apologizes and Calls Prank Videos Just for Entertainment (In Indonesian). Merdeka, 1.

Berryman, R., \& Kavka, M. (2018). Crying on YouTube: Vlogs, self-exposure and the productivity of negative affect. Convergence: The International Journal of Research into New Media Technologies, 24(1), 85-98. https://doi.org/10.1177/1354856517736981

Canazza, M. R. (2018). The Internet as a global public good and the role of governments and multilateral organizations in global internet governance. Meridiano 47 - Journal of Global Studies, 19. https:// doi.org/10.20889/M47e19007

Corbuzier, D. (2020). Indira Kalistha Apology and Clarification (In Indonesian). https://www.YouTube.com/watch?v=o_9FHjTKh3w

Diananto, W. (2020). Apart from Sarah Salsabila, these 6 YouTubers made negative content then apologized, several of them were arrested by the police (In Indonesia). Liputan6, 3.

Eisenhardt, K. M. (1989). Building Theories from Case Study Research. The Academy of Management Review, 14(4), 532-550.

Harvey, D. (2003). The new imperialism. Oxford University Press.

Kadar, D. Z., Ning, P., \& Ran, Y. (2018). Public ritual apology - A case study of Chinese. Discourse, Context \& Media, 26, 21-31. https://doi.org/10.1016/j.dcm.2018.01.003

Kompas. (2021a). Bengkulu High School Student Who Has Viral Video of Insulting Palestine Apologize, The Case?

(In Indonesian). Kompas. https://regional.kompas.com/read/2021/05/19/064627478/siswisma-bengkulu-yang-videonya-viral-hina-palestina-minta-maaf-kasusnya?page=all

Kompas. (2021b). New Provisions, All YouTube Videos Can Be Inserted With Ads (In Indonesian). Kompas. https://tekno.kompas.com/read/2021/05/24/06300007/ketentuan-baru-semua-videoYouTube-bakal-bisa-disisipi-iklan

Minton, A. (2013). Ground Control: Fear and Happiness in the Twenty-First-Century City. Penguin.

Murdock, G. (2011). Political Economies as Moral Economies: Commodities, Gifts, and Public Goods. In J. Wasko, G. Murdock, \& H. Sousa (Eds.), The handbook of political economy of communications (pp. 13-40). Wiley-Blackwell.

Sandlin, J. K., \& Gracyalny, M. L. (2018). Seeking sincerity, finding forgiveness: YouTube apologies as image repair. Public Relations Review, 44(3), 393-406. https://doi.org/10.1016/j.pubrev.2018.04.007

Sandlin, J. K., \& Gracyalny, M. L. (2020). Fandom, forgiveness and future support: YouTube apologies as crisis communication. Journal of Communication Management, 24(1), 1-18. https://doi.org/ 10.1108/JCOM-06-2019-0096

Tribun Jatim Official. (2021). A Mother who cursed COD (Cash on Delivery) Courier Now Apologize, Confess Guilt and Regret (In Indonesian). https://www.YouTube.com/watch?v=gkLODhkS-GQ

Tribunnews.com. (2020). A YouTuber Arrested for Insulting, Pretending to be in a Trance while Singing the Song "Aisyah, the Wife of the Prophet" (In Indonesian). https://www.YouTube.com/watch?v=3jF83xnMpJs

Tribunnews.com. (2021). A man who threatened the COD (Cash on Delivery) Courier using a sword, cried and apologized at the Ciputat Timur Police Headquarter (In Indonesian). https://www.YouTube.com/watch?v=BAeaQMa_TCc

Yang, A., \& Urminsky, O. (2018). The "Smile-Seeking" Giver: How Immediate Affective Reactions Motivate and Reward Gift-Giving. Psychological Science, 29(8), 1221-1233. https://doi.org/10.1287/ mnsc.2014.1999

Yin, R. K. (2018). Case study research and applications: Design and methods (Sixth edition). SAGE.

YouTube. (2021). About YouTube. YouTube. https://www.YouTube.com/intl/id/about/ 